\title{
Autoantibodies against CD38 (ADP-ribosyl Cyclase/Cyclic ADP-ribose Hydrolase) that Impair Glucose-induced Insulin Secretion in Noninsulin-dependent Diabetes Patients
}

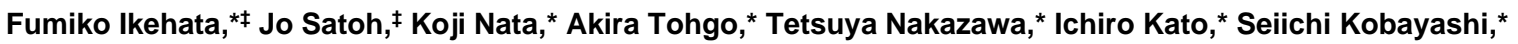 \\ Takako Akiyama, ${ }^{\star}$ Shin Takasawa, ${ }^{\star}$ Takayoshi Toyota, ${ }^{\ddagger}$ and Hiroshi Okamoto* \\ $*$ Department of Biochemistry, and ${ }^{\ddagger}$ Third Department of Internal Medicine, Tohoku University School of Medicine, Sendai \\ 980-8575, Japan
}

\begin{abstract}
Cyclic ADP-ribose (cADPR) has been shown to be a mediator for intracellular $\mathrm{Ca}^{2+}$ mobilization for insulin secretion by glucose in pancreatic $\beta$ cells, and CD38 shows both ADP-ribosyl cyclase to synthesize cADPR from $\mathrm{NAD}^{+}$and cADPR hydrolase to hydrolyze cADPR to ADP-ribose. We show here that $13.8 \%$ of Japanese non-insulin-dependent diabetes (NIDDM) patients examined have autoantibodies against CD38 and that the sera containing anti-CD38 autoantibodies inhibit the ADP-ribosyl cyclase activity of CD38 $(P \leq 0.05)$. Insulin secretion from pancreatic islets by glucose is significantly inhibited by the addition of the NIDDM sera with anti-CD38 antibodies $(P \leq 0.04-0.0001)$, and the inhibition of insulin secretion is abolished by the addition of recombinant $\mathrm{CD} 38(P \leq 0.02)$. The increase of cADPR levels in pancreatic islets by glucose was also inhibited by the addition of the sera $(P \leq 0.05)$. These results strongly suggest that the presence of anti-CD38 autoantibodies in NIDDM patients can be one of the major causes of impaired glucose-induced insulin secretion in NIDDM. $(J$. Clin. Invest. 1998. 102:395-401.) Key words: NAD ${ }^{+} \cdot$ second messenger $\cdot \mathrm{Ca}^{2+}$ mobilization $\bullet$ islets $\cdot$ Western blot
\end{abstract}

\section{Introduction}

Noninsulin-dependent diabetes mellitus (NIDDM) ${ }^{1}$ is a heterogeneous disorder characterized by defects in glucose-induced insulin secretion as well as insulin action (1). Abnormalities associated with NIDDM have been identified in insulin $(2,3)$, insulin receptor $(4,5)$, glucokinase $(M O D Y 2)(6,7), \mathrm{HNF}-4 \alpha$ (MODY1) (8), HNF-1 $\alpha$ (MODY3) (9), and mitochondrial genes $(10,11)$. However, these abnormalities seem to be rare in the common form of NIDDM, and the major causes of NIDDM remain elusive.

Address correspondence to Hiroshi Okamoto, Department of Biochemistry, Tohoku University School of Medicine, 2-1 Seiryo-machi, Aoba-ku, Sendai 980-8575, Miyagi, Japan. Phone: 81-22-717-8079; FAX: 81-22-717-8083.

Received for publication 4 September 1997 and accepted in revised form 14 May 1998.

1. Abbreviations used in this paper: cADPR, cyclic ADP-ribose; CD38, ADP-ribosyl cyclase/cyclic ADP-ribose hydrolase; NIDDM, non-insulin-dependent diabetes mellitus.

J. Clin. Invest.

(C) The American Society for Clinical Investigation, Inc. 0021-9738/98/07/0395/07 \$2.00

Volume 102, Number 2, July 1998, 395-401

http://www.jci.org
We have proposed a model for insulin secretion by glucose via cyclic ADP-ribose (cADPR)-mediated $\mathrm{Ca}^{2+}$ mobilization in pancreatic $\beta$ cells (12-15). In the process of glucose metabolism, millimolar concentrations of ATP are generated (16-18), inducing cADPR accumulation by inhibiting the cADPR hydrolase activity of CD38 (ADP-ribosyl cyclase/cADPR hydrolase) $(17,18)$, and cADPR acts as a second messenger for intracellular $\mathrm{Ca}^{2+}$ mobilization from the endoplasmic reticulum for insulin secretion $(12,19-21)$. Some controversial results have been reported using diabetic $\beta$ cells such as $o b / o b$ mouse islets and RINm5F cells (22-24). We have recently examined the $\mathrm{Ca}^{2+}$-releasing activity of these diabetic $\beta$ cell microsomes, compared it to that of the microsomes of normal $\beta$ cells such as C57BL/6J mouse islets, and found that the $\mathrm{Ca}^{2+}$ release responses of these diabetic $\beta$ cell microsomes were quite different from those of normal islet microsomes $(15,21)$. Microsomes from $\mathrm{C} 57 \mathrm{BL} / 6 \mathrm{~J}$ mouse islets, as well as Wistar rat islets, released $\mathrm{Ca}^{2+}$ in response to cADPR, but scarcely in response to $\mathrm{IP}_{3}$. In contrast to normal islet microsomes, $o b / o b$ mouse islet microsomes released only a small amount of $\mathrm{Ca}^{2+}$ by cADPR, but released much $\mathrm{Ca}^{2+}$ by $\mathrm{IP}_{3}$. RINm5F cell microsomes responded well to $\mathrm{IP}_{3}$ to release $\mathrm{Ca}^{2+}$, but did not respond to cADPR. Two systems for intracellular $\mathrm{Ca}^{2+}$ mobilization (cADPR- and $\mathrm{IP}_{3}$-dependent systems) thus appear to be differentially used in $\beta$ cells, depending on whether the condition is physiological or pathological. Furthermore, we and others have reported that the CD38 expression was decreased in islets of animal models of diabetes such as GK rats (25) and $o b / o b$ mice (21).

We have also reported that a monoclonal antibody against CD38 inhibited the enzymic activities of CD38 (17), suggesting the possibility that anti-CD38 antibodies cause the failure of cADPR accumulation in pancreatic $\beta$ cells in response to glucose stimulation, thereby impairing glucose-induced insulin secretion. In the present study, we examined the presence of autoantibodies against CD38 in the sera of 377 Japanese NIDDM patients and 75 controls by immunoblot and found $13.8 \%$ of NIDDM patients had autoantibodies against CD38, whereas only 1 in $75(1.3 \%)$ in the control group exhibited an extremely low level of autoantibody. The sera of patients with autoantibodies against CD38 inhibited the ADP-ribosyl cyclase activity of CD38, the increase of cADPR levels by glucose in islets, and glucose-induced insulin secretion.

\section{Methods}

Subjects. 377 subjects with NIDDM were randomly selected from outpatients of Tohoku University Hospital (Sendai, Japan) (mean age $60.7 \mathrm{yr}$, range 28-88). 75 nondiabetic subjects screened had no family history of diabetes and had normal fasting plasma glucose levels of $<6.1 \mathrm{mmol} / 1\left(110 \mathrm{mg} / \mathrm{dl}\right.$ ) and $\mathrm{HbA}_{1 \mathrm{c}}<6.0 \%$ (mean age $50.7 \mathrm{yr}$, range 17-81). The diagnosis of NIDDM was based on WHO criteria 
(26) before the initiation of therapy. All patients and controls were informed of the purpose of the study and their consent was obtained. This study was approved by the ethics committee of Tohoku University Hospital. Blood samples were incubated overnight at $4^{\circ} \mathrm{C}$, fibrin clots were removed, and sera were stored at $-80^{\circ} \mathrm{C}$.

Screening of anti-CD38 antibodies. Recombinant CD38 was prepared as a maltose-binding protein-CD38 fusion protein of $68 \mathrm{kD}$, as described previously (18). Recombinant CD38 $(20 \mu \mathrm{g})$ was electrophoresed on $10 \%$ SDS-polyacrylamide gel $(9 \times 6 \mathrm{~cm})$ and transferred to Immobilon P (Millipore, Bedford, MA; 14, 17, 18, 27). After blocking with $5 \%$ nonfat dry milk, the blots were incubated with NIDDM sera using a Screener Blotter Mini56 (Sanplatec, Osaka, Japan). The NIDDM sera were diluted 1,024 times with $5 \%$ milk powder. After rinsing, the membranes were incubated with a rabbit anti-human antibody labeled with horseradish peroxidase (American Qualex, La Mirada, CA) at a dilution of 1/1,600 and developed using the enhanced chemiluminescence detection system (Amersham Corp., Arlington Heights, IL) as described $(14,17,18,27)$. The band intensities of the blots were measured using National Institutes of Health (Bethesda, MD) image software. The density was standardized using the value of an internal control sample and expressed as a relative value. In a preabsorption experiment, diabetic sera with autoantibodies against CD38 were incubated with or without $100 \mu \mathrm{g} / \mathrm{ml}$ recombinant CD38 in 5\% milk powder overnight at $4^{\circ} \mathrm{C}(28)$. Recombinant rat CD38 was prepared essentially as described (18), except that rat CD38 cDNA-encoding amino acids 45-303 (29) were used in place of human CD38 cDNA-encoding amino acids 45-300 $(17,18,30)$.

Data analysis. Results of two-tailed Student's $t$ test comparing the response to each addition versus the control (no addition) are shown. The frequency distribution of positive values (mean $\pm 3 \mathrm{SD}$ for nondiabetic control) was compared by $\chi^{2}$ test. Correlation coefficient and simple regression analysis were performed using StatView 4.5 (Abacus Concepts, Inc., Berkeley, CA).

Enzyme assays. ADP-ribosyl cyclase and cADPR hydrolase assays were performed as described $(14-18,27)$. Briefly, $50 \mathrm{ng}$ of CD38 were incubated for $5 \mathrm{~min}$ at $37^{\circ} \mathrm{C}$ in $0.1 \mathrm{ml}$ of phosphate buffered saline $\left(137 \mathrm{mM} \mathrm{NaCl}, 2.7 \mathrm{mM} \mathrm{KCl}, 8.1 \mathrm{mM} \mathrm{Na}_{2} \mathrm{HPO}_{4}, 1.5 \mathrm{mM} \mathrm{KH}_{2} \mathrm{PO}_{4}\right.$, $\mathrm{pH}$ 7.4) with $0.2 \mathrm{mM} \mathrm{NAD}^{+}$containing $5 \mu \mathrm{Ci}$ of ${ }^{32} \mathrm{P}^{3} \mathrm{NAD}^{+}(\mathrm{Du}-$ Pont-NEN, Boston, MA) for ADP-ribosyl cyclase or with $0.2 \mathrm{mM}$ cADPR containing $5 \mu \mathrm{Ci}$ of $\left[{ }^{32} \mathrm{P}\right] \mathrm{cADPR}$, prepared as described previously $(12,14-18,27)$ for cADPR hydrolase. Reaction products were analyzed by $\operatorname{HPLC}(12,14-17,27)$ using a flow scintillation analyzer (Flow-One Beta-525TR; Packard, Meriden, CT). The protein concentration was measured by the method of Bradford (31) using BSA as a standard.

Insulin secretion. Pancreatic islets were isolated from male Wistar rats $(12,19)$ weighing $250-300 \mathrm{~g}$. Islets $(20 /$ tube) were preincubated at $37^{\circ} \mathrm{C}$ for $30 \mathrm{~min}$ in $0.1 \mathrm{ml}$ of Krebs-Ringer's bicarbonate buffer (KRB) containing $0.2 \%$ BSA and $2.8 \mathrm{mM}$ glucose with an antiCD38 monoclonal antibody or human serum (finally to $10 \%$ ) in the presence or absence of $\mathrm{CD} 38$ under an atmosphere of $95 \% \mathrm{O}_{2}, 5 \%$ $\mathrm{CO}_{2}$. After the preincubation, the medium was discarded and islets were incubated in $0.1 \mathrm{ml}$ of fresh KRB buffer containing $0.2 \%$ BSA and $20 \mathrm{mM}$ glucose with an anti-CD38 monoclonal antibody or human serum in the presence or absence of CD38. After $30 \mathrm{~min}$ of incubation, the medium was removed from the islets, and the insulin content of the medium was determined by RIA using a rat insulin RIA kit (Amersham Corp.) and rat insulin standard (19). The monoclonal antibody against human CD38 was T16 $(14-18,27)$ (Cosmo Bio Co., Ltd., Tokyo, Japan).

cADPR measurement. Pancreatic islets were isolated from Wistar male rats (250-350 g, SLC, Hamamatsu, Japan), which were fasted for $24 \mathrm{~h}$ before the experiments, by the collagenase procedure using Hanks solution containing $2.8 \mathrm{mM}$ glucose $(3,9,12,21)$. Hand-picked islets (300-500/tube) were immediately incubated for $10 \mathrm{~min}$ at $37^{\circ} \mathrm{C}$ in $2 \mathrm{ml}$ of KRB containing $0.2 \%$ BSA and $20 \mathrm{mM}$ glucose with or without NIDDM sera under an atmosphere of $95 \% \mathrm{O}_{2} / 5 \% \mathrm{CO}_{2}$. cADPR was extracted and concentrated as described (21). The recov- ery of cADPR, monitored by the recovery of $\left[{ }^{3} \mathrm{H}\right] \mathrm{cADPR}$ added in each homogenate, was $43.8 \pm 0.62 \%(n=33)$. Correction was introduced for the recovery of cADPR. The cADPR content of the cell extracts was measured by a RIA as described $(21,32)$.

\section{Results}

Inhibition of insulin secretion by an anti-CD38 antibody. We isolated pancreatic islets from male Wistar rats, incubated them with a monoclonal antibody against CD38 (T16), which inhibits the enzymic activity of CD38 (17) and reacts with rat CD38 (27), and measured the glucose-induced insulin secretion. As shown in Fig. 1, the antibody inhibited the glucose-induced insulin secretion in a dose-dependent manner. Therefore, if antiCD38 antibodies are present in human, glucose-induced insulin secretion could be impaired and result in NIDDM.

Detection of anti-CD38 antibodies in NIDDM patients. We examined the existence of anti-CD38 antibodies in Japanese NIDDM patients. As shown in Fig. $2 A$, some NIDDM sera reacted with CD38 (lanes 1 and 3 ). When the NIDDM serum was incubated with CD38 to absorb anti-CD38 antibodies, the immunoreactive signal was abolished (Fig. $2 \mathrm{~B}$ ), indicating that the signals in Western blot seen in Fig. $2 A$ represent antiCD38 antibodies. We then screened sera for autoantibodies against CD38 in 377 Japanese NIDDM patients and 75 nondiabetic controls by Western blot method. Histograms of relative anti-CD38 values are shown in Fig. $3 \mathrm{~A}$. In nondiabetic subjects, the relative values were within the mean \pm 3 SD except for one subject. On the other hand, the distribution of relative anti-CD38 values showed two clear peaks in NIDDM pa-

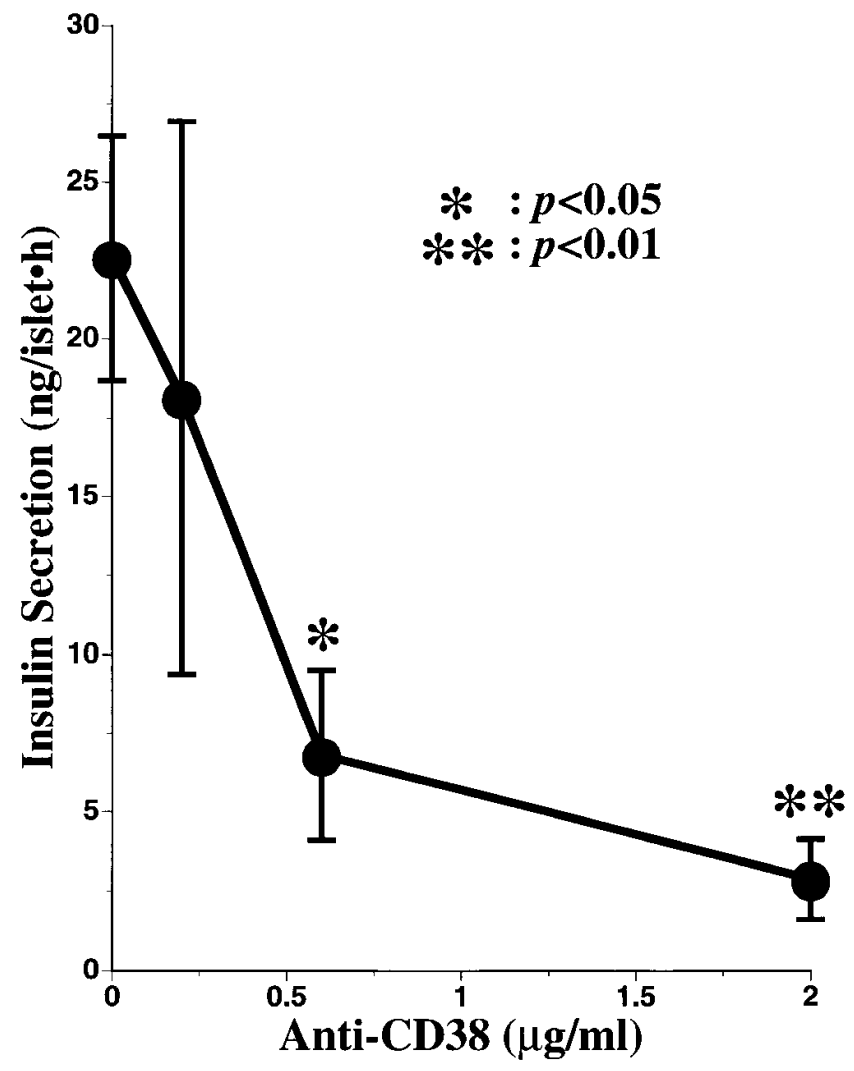

Figure 1. Inhibition of glucose-induced insulin secretion by a monoclonal antibody against CD38. 

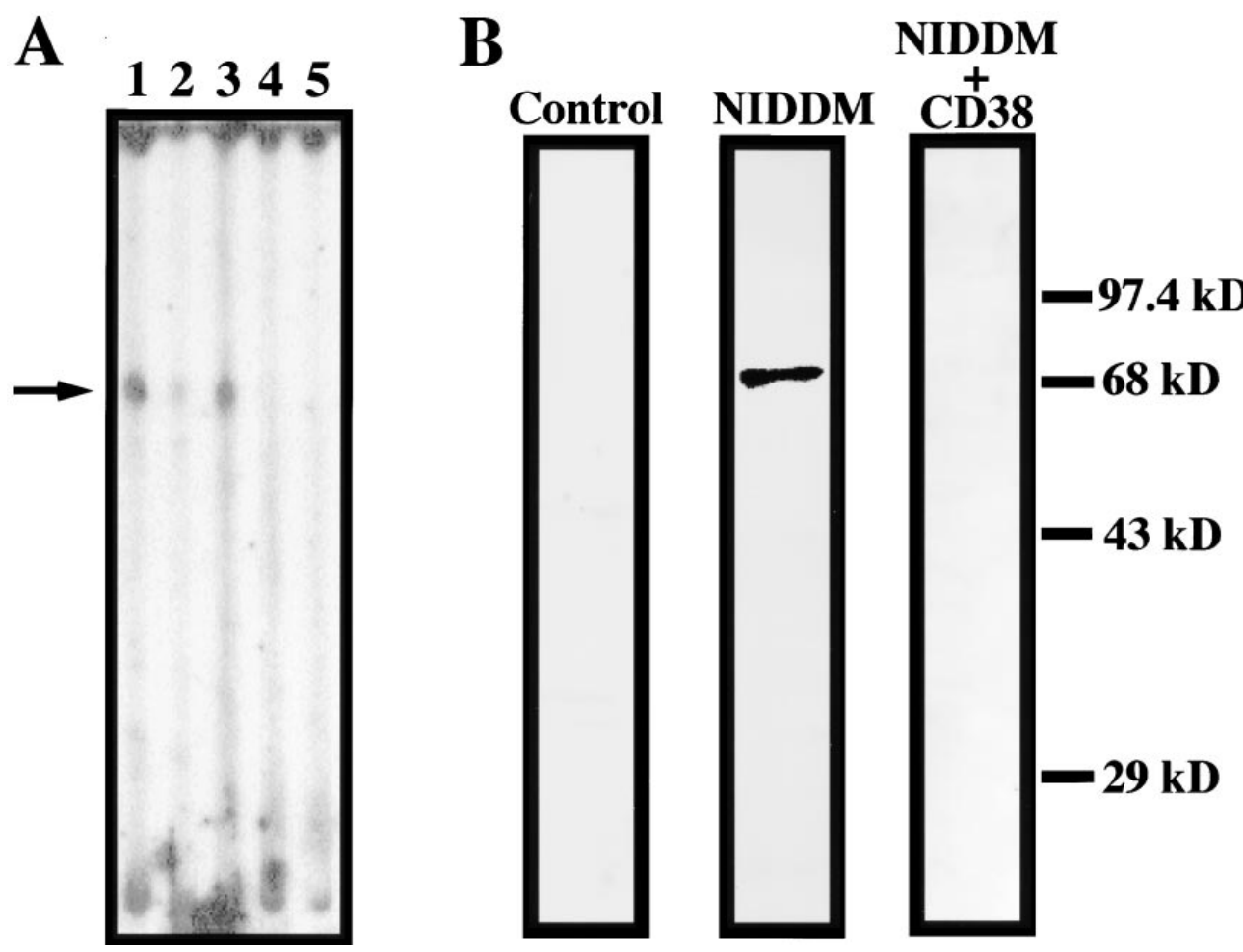

Figure 2. Detection of autoantibodies against CD38 in NIDDM sera by Western blotting. $(A)$ Screening of anti-CD38 autoantibodies in NIDDM patients. Screening was carried out as described in Methods. The position of recombinant CD38 is marked by the arrow. (B) Preabsorption of anti-CD38 antibodies. NIDDM serum $(A$, lane 1$)$ was incubated with or without human CD38 and used for Western blot. Nondiabetic serum was used as control.

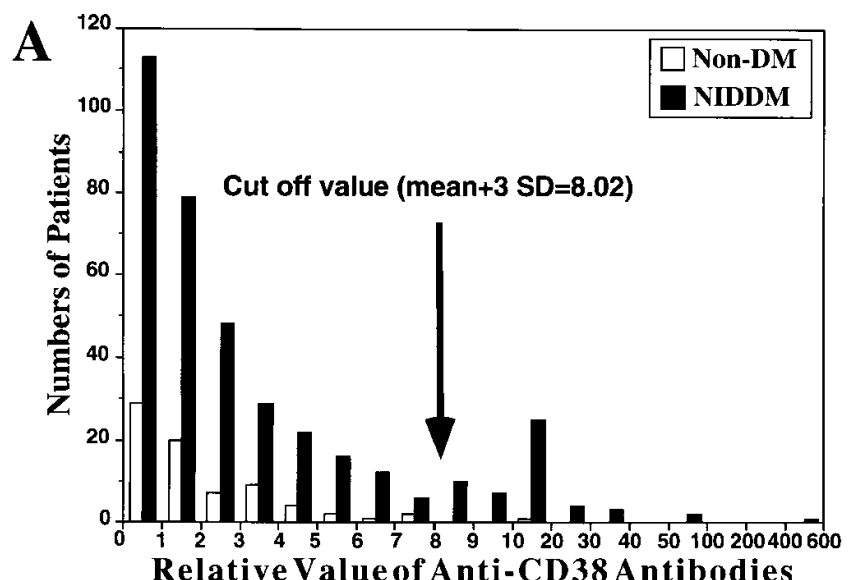

Table I. General Characteristics of Study Subjects

\begin{tabular}{|c|c|c|c|}
\hline & CD38 $(+)$ & CD38 (-) & $P$ Values \\
\hline $\operatorname{Sex}(M / F)$ & $25 / 27$ & $157 / 168$ & NS \\
\hline Age (yr) & $59.08 \pm 2.23$ & $61.20 \pm 0.73$ & NS \\
\hline Known duration of diabetes $(\mathrm{yr})$ & $12.50 \pm 1.51$ & $14.73 \pm 0.53$ & NS \\
\hline Fasting plasma glucose $(\mathrm{mmol} / \mathrm{l})$ & $7.40 \pm 0.32$ & $7.71 \pm 0.13$ & NS \\
\hline $\mathrm{HbA}_{1 \mathrm{c}}(\%)$ & $7.43 \pm 0.19$ & $7.76 \pm 0.30$ & NS \\
\hline $\operatorname{BMI}\left(\mathrm{kg} / \mathrm{m}^{2}\right)$ & $23.10 \pm 0.51$ & $22.83 \pm 0.19$ & NS \\
\hline C-peptide (nmol/l) & $1.58 \pm 0.18$ & $1.13 \pm 0.059$ & NS \\
\hline Treatment (diet/oral agents/insulin) & $16 / 12 / 24$ & $63 / 107 / 155$ & NS \\
\hline Autoimmune disease (\%) & 4.3 & 5.8 & NS \\
\hline Anti-GAD (U/ml) & $3.14 \pm 0.17$ & $6.56 \pm 3.01$ & NS \\
\hline
\end{tabular}

NS: $P>0.05$.

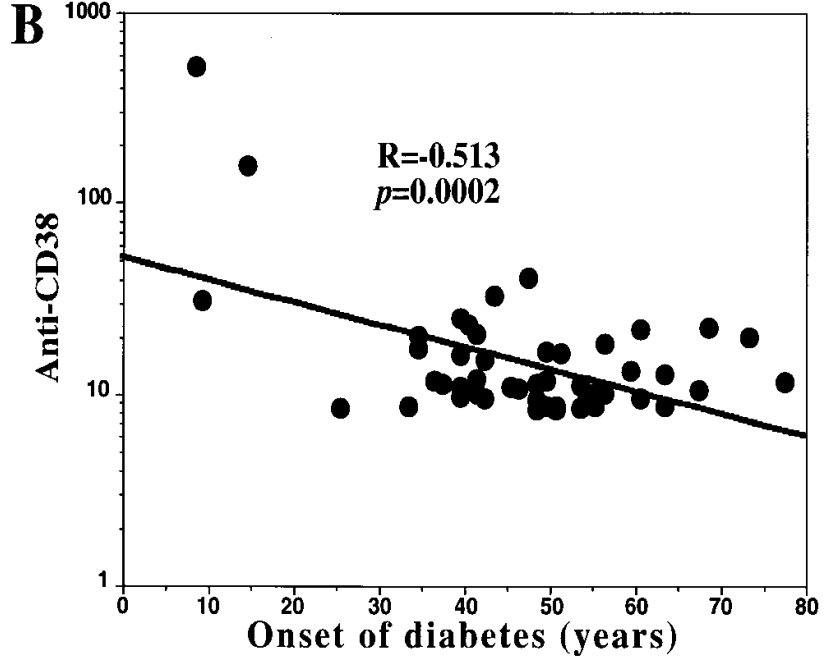

tients: one was below the mean \pm 3 SD of nondiabetic controls and the other was over the mean \pm 3 SD. Therefore, it is reasonable to consider the value of mean \pm 3 SD (8.02) of nondiabetic controls as a cut-off value. 52 of $377(13.8 \%)$ patients with NIDDM versus $1 / 75(1.3 \%)$ of nondiabetic controls had anti-CD38 antibodies $\left(P=0.0022\right.$ in $\chi^{2}$ test). Although general characteristics such as sex ratio, age, known duration of diabetes, fasting blood glucose, glycosylated hemoglobin, body mass

Figure 3. (A) Relative value of anti-CD38 autoantibodies in NIDDM and nondiabetic sera. An arrow indicates mean \pm 3 SD of nondiabetic control. The levels of CD38 antibodies expressed as an index value relative to a standard serum. Values above mean $\pm 3 \mathrm{SD}$ of the control samples were regarded as antibody positive. $(B)$ Inverse relationship between anti-CD38 value and age of diabetes onset. 

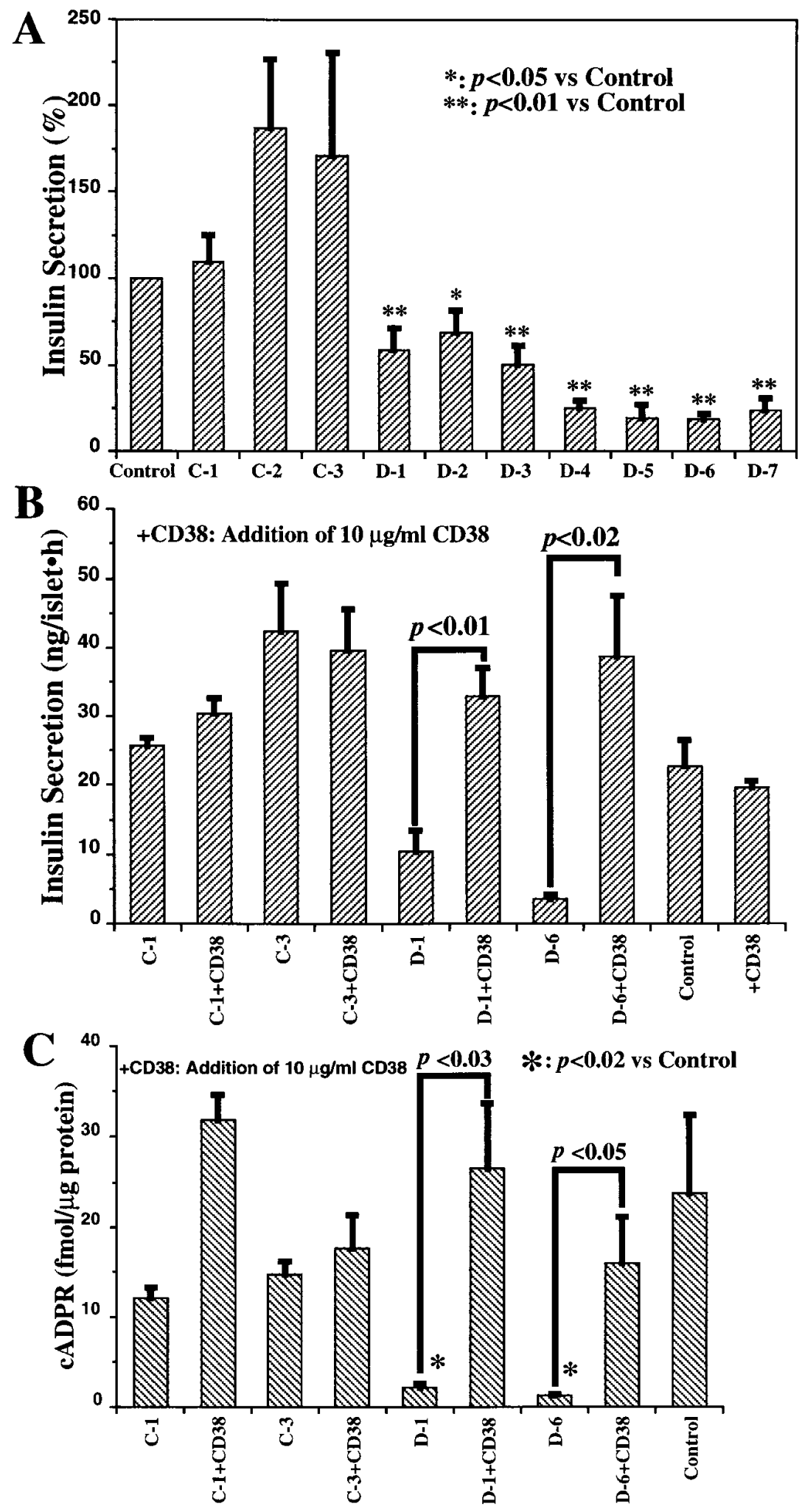

Figure 4. Inhibition of glucose-induced insulin secretion and cADPR increase by anti-CD38 antibodies. $(A)$ Inhibition of insulin secretion by antiCD38 positive NIDDM serum. The release of insulin from isolated rat islets was measured as described in Methods. C-1-C-3 indicate control sera and D-1-D-7 indicate diabetic sera containing anti-CD38 antibodies. Values are expressed by percent (mean \pm SE, $n=3-11$ ) of control without serum. The average insulin secretion of control was $20.47 \pm 2.36 \mathrm{ng} / \mathrm{islet} / \mathrm{h}$. Results of twotailed Student's $t$ test show the response to each addition as compared to the control. *: $P<0.05$; **: $P<0.01$. (B) Abolishment of the inhibition of insulin secretion by the addition of CD38. Islets were incubated in the presence or absence of $10 \mu \mathrm{g} / \mathrm{ml}$ human CD38, and secreted insulin was measured by RIA $(n=3-6)$. (C) Inhibition of cADPR increase by anti-CD38 positive NIDDM sera and its abolishment by CD38. Islets were incubated in the presence or absence of $10 \mu \mathrm{g} / \mathrm{ml}$ human CD38 and the cADPR content was measured by RIA $(n=3)$. Results of two-tailed Student's $t$ test show the response to each addition as compared to the control. *: $P<0.02$.

index, serum C-peptide, the incidence of autoimmune diseases, such as systemic lupus erythematosus, rheumatoid arthritis, and Hashimoto's thydoiditis, and anti-glutamic acid decarboxylase 65 (GAD65) antibodies between anti-CD38 antibody, positive and negative NIDDM patients did not show significant differences (Table I). There was an inverse correla- tion between the age of diabetes onset and the anti-CD38 antibody value as determined by simple regression analysis $(P=$ 0.0002, $r=-0.513$ ) (Fig. 3 B).

Inhibition of glucose-induced insulin secretion and $c A D P R$ increase. Of 52 NIDDM sera reacting with human CD38, 7 NIDDM sera exhibited a positive reaction to recombinant rat 
CD38 (D-1-7 in Fig. $4 A$ ). We examined the effects of the NIDDM sera that reacted with rat CD38 on glucose-induced insulin secretion from isolated rat islets. All of the seven NIDDM sera significantly inhibited glucose-induced insulin secretion (Fig. $4 A$ ) and the sera inhibited the insulin secretion in a dose-dependent manner (data not shown). In contrast to the glucose-induced insulin secretion, the sera did not affect basal insulin secretion $(92.7 \pm 7.75 \%$ of control without the sera). The addition of recombinant CD38 abolished the inhibitory effect of the NIDDM sera, whereas nondiabetic control sera did not exhibit such an inhibitory effect on the glucoseinduced insulin secretion (Fig. 4, $A$ and $B$ ). Furthermore, the cADPR levels in islets incubated with the NIDDM sera were significantly reduced and the reduction was attenuated by the addition of recombinant CD38 (Fig. $4 C$ ), suggesting that the inhibition of insulin secretion (Fig. $4, A$ and $B$ ) is due to changes in cADPR levels regulated by CD38.

Modulation of CD38 enzymic activities by anti-CD38 antibodies. The effects of the NIDDM sera containing anti-CD38 antibodies on enzymic activities were next examined. As shown in Fig. 5, the ADP-ribosyl cyclase activity of CD38 was significantly inhibited by the addition of NIDDM sera containing anti-CD38 antibodies, and the cADPR hydrolase activity of CD38 was rather activated by the addition of NIDDM sera. These results explain well why the NIDDM sera inhibited glucose-induced insulin secretion (Fig. 4). Usually, in the process of glucose metabolism, millimolar concentrations of ATP are generated, which inhibits the cADPR hydrolase activity of CD38 to induce the accumulation of cADPR in $\beta$ cells, and cADPR acts as a second messenger for intracellular $\mathrm{Ca}^{2+}$ mobilization to secrete insulin. When anti-CD38 antibodies are present, the ADP-ribosyl cyclase activity of CD38 in pancreatic $\beta$ cells would be inhibited and, in contrast, the cADPR hydrolase activity would be activated. Consequently, cADPR accumulation in pancreatic $\beta$ cells can scarcely occur in response to glucose stimulation and the glucose-induced insulin secretion is thereby impaired.

\section{Discussion}

In the present study, we have shown that anti-CD38 autoantibodies exist in sera from a large proportion of patients with NIDDM, that the antibodies inhibit the ADP-ribosyl cyclase and activate the cADPR hydrolase of CD38, and inhibit both the increase of $c A D P R$ in islets and the insulin secretion from pancreatic $\beta$-cells by glucose, a finding that reinforces the concept of this protein being involved in the glucose-induced insulin secretion via cADPR production, as proposed in our recent reviews (13-15). CD38 was originally identified as a cell surface antigen and also localized both in cell surface and intracellular fractions (16-18). Therefore, the antibodies against CD38 in patient sera can interact with CD38. The effects of autoantibodies found in NIDDM patients and a monoclonal antibody on the cADPR hydrolase activity of CD38 were different, but the ADP-ribosyl cyclase activity of CD38 was inhibited by both antibodies (Fig. 5 and Ref. 17). The ratio of the ADPribosyl cyclase to the cADPR hydrolase activity of CD38 is 1:5-10 $(17,18)$. Therefore, if the ADP-ribosyl cyclase activity is significantly inhibited, the cADPR content should be reduced even if the cADPR hydrolase activity is inhibited. In fact, as shown in Fig. $4 C$, the cADPR contents in islets treated with anti-CD38 positive antisera were significantly lower than those of controls. The data in the present study together with evidence deriving from experimental studies in mouse islets (33) and the observation of a CD38 gene mutation in Japanese NIDDM patients (34) suggest that abnormalities of CD38 in $\beta$ cells are related to the pathogenesis of NIDDM.

Among the NIDDM patients without insulin treatment $(n=198)$, the frequency of anti-CD38 positive patients was significantly lower in the NIDDM group controlled by oral hypoglycemic agents (12 positive in $119,10.1 \%$ ) than in the group treated by diet control (16 positive in 79, 20.3\%) $(P=$ 0.044 in $\chi^{2}$ test). In insulin secretion by glucose, both $\mathrm{Ca}^{2+}$ influx from extracellular spaces and $\mathrm{Ca}^{2+}$ mobilization from the intracellular $\mathrm{Ca}^{2+}$ pool, the endoplasmic reticulum, are thought to be important $(15,35)$. Most oral hypoglycemic agents activate $\mathrm{Ca}^{2+}$ influx from extracellular spaces (36), whereas CD38 participates in intracellular $\mathrm{Ca}^{2+}$ mobilization from the endoplasmic reticulum (12-21). The majority of NIDDM patients whose blood glucose levels could be controlled by hypoglycemic agents was thought to be normal in intracellular $\mathrm{Ca}^{2+}$ mobilization, but to have some abnormalities in the $\mathrm{Ca}^{2+}$ influx machinery from extracellular spaces, and it, therefore, appears reasonable that the frequency of anti-CD38 positive patients controlled by oral hypoglycemic agents was lower than that of the diet control group.

\section{ADP-ribosyl cyclase cADPR hydrolase}

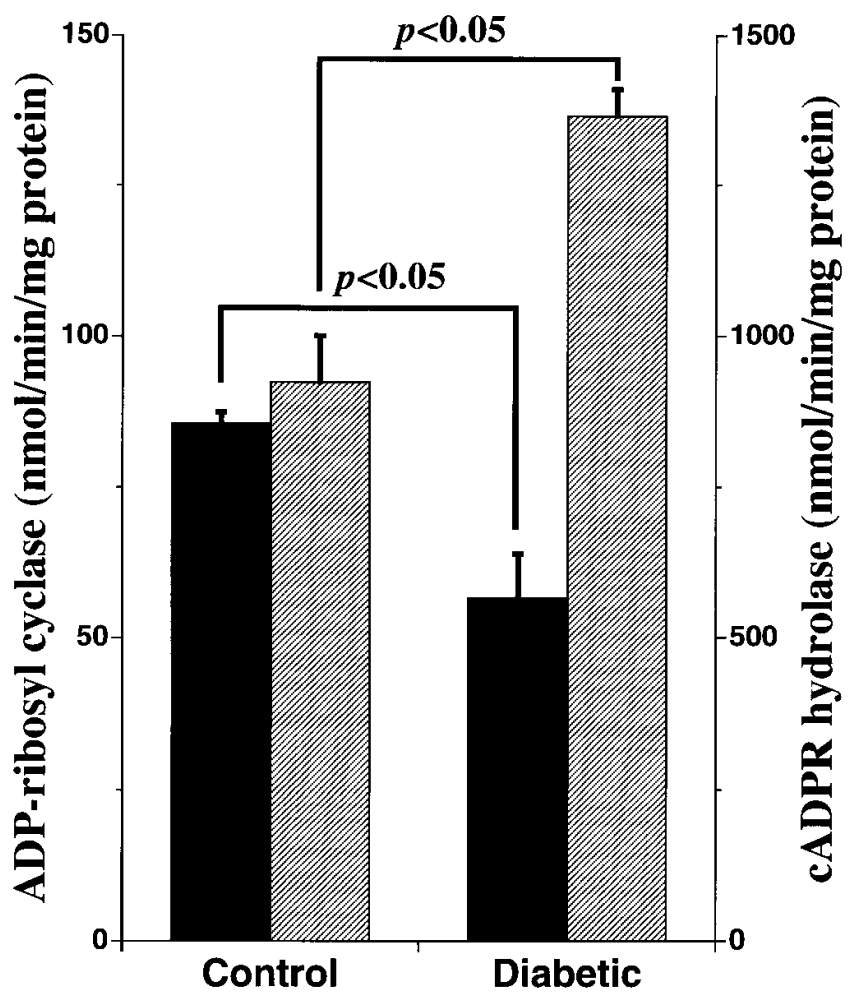

Figure 5. Effects of diabetic sera containing anti-CD38 antibodies on ADP-ribosyl cyclase and cADPR hydrolase activities of CD38. ADPribosyl cyclase and CADPR hydrolase activities of CD38 were measured in the presence of anti-CD38 antibody positive diabetic sera $(n=5)$ or anti-CD38 negative control sera $(n=3)$. The final concentration of serum in the reaction was $10 \%$. Enzyme activities are expressed by $\mathrm{nmol} / \mathrm{min} / \mathrm{mg}$ protein in ordinates. 
We have also examined anti-CD38 autoantibodies in Japanese insulin-dependent diabetes patients $(n=69)$ and found seven anti-CD38 positive patients $(10.1 \%)\left(P=0.0211\right.$ in $\chi^{2}$ test). In addition, Taminato et al. reported that anti-CD38 antibodies were frequently detected in 7-11-wk-old NOD mice, whereas the antibodies could not be detected in 5-wk-old NOD mice (37). It is quite possible that CD38 acts as an autoantigen when pancreatic $\beta$ cells are destroyed and that antiCD38 autoantibodies are also involved in the development of insulin-dependent diabetes patients.

CD38 was initially identified as a cell surface marker protein of leukocytes and has been thought to be involved in a variety of immune system functions, but the incidence of autoimmune diseases such as systemic lupus erythematosus, rheumatoid arthritis, and Hashimoto's thydoiditis was not different between the patients with anti-CD38 autoantibodies and those without the antibodies (Table I). Further studies, such as the screening of anti-CD38 in autoimmune diseases or the production and analysis of CD38 deficient mice, may clarify some immune system functions of CD38.

\section{Acknowledgments}

The authors wish to thank Toshiaki Katada (Department of Physiological Chemistry, Faculty of Pharmaceutical Sciences, University of Tokyo, Tokyo, Japan) for kindly providing an antiserum against cADPR, Hideo Kumagai and Yoji Kumagai for technical assistance, and Brent Bell for valuable assistance in preparing the manuscript for publication (all from Tohoku University School of Medicine, Sendai, Japan).

This work was supported in part by grants-in-aid from the Ministry of Education, Science, Sports, and Culture (Tokyo, Japan), and the Kanae Foundation of Research for New Medicine, and was submitted in partial fulfillment of the degree of Doctor of Medical Science at Tohoku University (Sendai, Japan) (F. Ikehata).

\section{References}

1. DeFronzo, R.A., R.C. Bonadonna, and E. Ferrannini. 1992. Pathogenesis of NIDDM: a balanced overview. Diabetes Care. 15:318-368.

2. Steiner, D.F., H.S. Tager, S.J. Chan, K. Nanjo, T. Sanke, and A.H. Rubenstein. 1990. Lessons learned from molecular biology of insulin gene mutations. Diabetes Care. 13:600-609.

3. Tager, H.S. 1990. Abnormal products of the human insulin gene. In Molecular Biology of the Islets of Langerhans. H. Okamoto, editor. Cambridge University Press, Cambridge, UK. 263-286.

4. Taylor, S.I., A. Cama, and D. Accili. 1992. Mutations in the insulin receptor gene. Endocr. Rev. 13:566-595.

5. White, M.F., and C.R. Kahn. 1994. Molecular aspects of insulin action. In Joslin's Diabetes Mellitus, 13th Ed. C.R. Kahn and G.C. Weir, editors. Lea \& Febiger, Philadelphia, PA. 139-162.

6. Froguel, P., H. Zouali, N. Vionnet, G. Velho, M. Vaxillaire, F. Sun, S. Lesage, M. Stoffel, J. Takeda, P. Passa, et al. 1993. Familial hyperglycemia due to mutation in glucokinase: definition of a subtype of diabetes mellitus. $N$. Eng. J. Med. 328:697-702.

7. Hattersley, A.T., R.C. Turner, M.A. Permutt, P. Patel, Y. Tanizawa, K.C. Chiu, S. O'Rahilly, P.J. Watkins, and J.S. Wainscoat. 1992. Linkage of type 2 diabetes to the glucokinase gene. Lancet. 339:1307-1310.

8. Yamagata, K., H. Furuta, N. Oda, P.J. Kaisaki, S. Menzel, N.J. Cox, S.S. Fajans, S. Signorini, M. Stoffel, and G.I. Bell. 1996. Mutations in hepatocyte nuclear factor- $4 \alpha$ gene in maturity-onset diabetes of the young (MODY1). Nature. 384:458-460.

9. Yamagata, K., N. Oda, P.J. Kaisaki, S. Menzel, H. Furuta, M. Vaxillaire, L. Southam, R.D. Cox, G.M. Lathrop, V.V. Boriraj, et al. 1996. Mutations in the hepatocyte nuclear factor- $1 \alpha$ gene in maturity-onset diabetes of the young (MODY3). Nature. 384:455-458.

10. Ballinger, S.W., J.M. Shoffner, E.V. Hedaya, I. Trounce, M.A. Polak, D.A. Koontz, and D.C. Wallace. 1992. Maternally transmitted diabetes and deafness associated with a $10.4 \mathrm{~kb}$ mitochondrial DNA deletion. Nat. Genet. 1: $11-15$.
11. van der Ouweland, J.M.V., H.H.P.J. Lemkes, W. Ruitenbeek, L.A. Sandkuijl, M.F. de Vijlder, P.A.A. Struyvenberg, J.J.P. van de Kamp, and J.A. Maassen. 1992. Mutation in mitochondrial tRNA ${ }^{\mathrm{Leu}(U U R)}$ gene in a large pedigree with maternally transmitted type II diabetes mellitus and deafness. Nat. Genet. 1:368-371.

12. Takasawa, S., K. Nata, H. Yonekura, and H. Okamoto. 1993. Cyclic ADP-ribose in insulin secretion from pancreatic $\beta$ cells. Science. 259:370-373.

13. Okamoto, H., S. Takasawa, and A. Tohgo. 1995. New aspects of the physiological significance of NAD, poly ADP-ribose and cyclic ADP-ribose. Biochimie (Paris). 77:356-363.

14. Okamoto, H., S. Takasawa, A. Tohgo, K. Nata, I. Kato, and N. Noguchi. 1997. Synthesis and hydrolysis of cyclic ADP-ribose by human leukocyte antigen CD38: inhibition of hydrolysis by ATP and the physiological significance. Methods Enzymol. 280:306-318.

15. Okamoto, H., S. Takasawa, and K. Nata. 1997. The CD38-cyclic ADPribose signalling system in insulin secretion: molecular basis and clinical implications. Diabetologia. 40:1485-1491.

16. Kato, I., S. Takasawa, A. Akabane, O. Tanaka, H. Abe, T. Takamura, Y. Suzuki, K. Nata, H. Yonekura, T. Yoshimoto, and H. Okamoto. 1995. Regulatory role of CD38 (ADP-ribosyl cyclase/cyclic ADP-ribose hydrolase) in insulin secretion by glucose in pancreatic $\beta$ cells. Enhanced insulin secretion in CD38-expressing transgenic mice. J. Biol. Chem. 270:30045-30050.

17. Takasawa, S., A. Tohgo, N. Noguchi, T. Koguma, K. Nata, T. Sugimoto, H. Yonekura, and H. Okamoto. 1993. Synthesis and hydrolysis of cyclic ADPribose by human leukocyte antigen CD38 and inhibition of the hydrolysis by ATP. J. Biol. Chem. 268:26052-26054.

18. Tohgo, A., H. Munakata, S. Takasawa, K. Nata, T. Akiyama, N. Hayashi, and H. Okamoto. 1997. Lysine 129 of CD38 (ADP-ribosyl cyclase/cyclic ADP-ribose hydrolase) participates in the binding of ATP to inhibit the cyclic ADP-ribose hydrolase. J. Biol. Chem. 272:3879-3882.

19. Takasawa, S., A. Ishida, K. Nata, K. Nakagawa, N. Noguchi, A. Tohgo, I. Kato, H. Yonekura, H. Fujisawa, and H. Okamoto. 1995. Requirement of calmodulin-dependent protein kinase II in cyclic ADP-ribose-mediated intracellular $\mathrm{Ca}^{2+}$ mobilization. J. Biol. Chem. 270:30257-30259.

20. Noguchi, N., S. Takasawa, K. Nata, A. Tohgo, I. Kato, F. Ikehata, H. Yonekura, and H. Okamoto. 1997. Cyclic ADP-ribose binds to FK506-binding protein 12.6 to release $\mathrm{Ca}^{2+}$ from islet microsomes. J. Biol. Chem. 272:31333136.

21. Takasawa, S., T. Akiyama, K. Nata, M. Kuroki, A. Tohgo, N. Noguchi, S. Kobayashi, I. Kato, T. Katada, and H. Okamoto. 1998. Cyclic ADP-ribose and inositol 1,4,5-trisphosphate as alternate second messengers for intracellular $\mathrm{Ca}^{2+}$ mobilization in normal and diabetic $\beta$-cells. J. Biol. Chem. 273:24972500 .

22. Islam, M.S., O. Larsson, and P.-O. Berggren. 1993. Cyclic ADP-ribose in $\beta$ cells. Science. 262:584-585.

23. Rutter, G.A., J.-M. Theler, and C.B. Wollheim. 1994. $\mathrm{Ca}^{2+}$ stores in insulin-secreting cells: lack of effect of cADP ribose. Cell Calcium. 16:71-80.

24. Webb, D.-L., M.S. Islam, A.M. Efanov, G. Brown, M. Kohler, O. Larsson, and P.-O. Berggren. 1996. Insulin exocytosis and glucose-mediated increase in cytoplasmic free $\mathrm{Ca}^{2+}$ concentration in the pancreatic $\beta$-cell are independent of cyclic ADP-ribose. J. Biol. Chem. 271:19074-19079.

25. Matsuoka, T., Y. Kajimoto, H. Watada, Y. Umayahara, M. Kubota, R. Kawamori, Y. Yamasaki, and T. Kamada. 1995. Expression of CD38 gene, but not of mitochondrial glycerol-3-phosphate dehydrogenase gene, is impaired in pancreatic islets of GK rats. Biochem. Biophys. Res. Commun. 214:239246

26. Diabetes mellitus: report of a WHO study group. 1985. WHO Tech. Rep. Ser. 727:1-113.

27. Ebihara, S., T. Sasaki, W. Hida, Y. Kikuchi, T. Oshiro, S. Shimura, S Takasawa, H. Okamoto, A. Nishiyama, N. Akaike, and K. Shirato. 1997. Role of cyclic ADP-ribose in ATP-activated potassium currents in alveolar macrophages. J. Biol. Chem. 272:16023-16029.

28. Ravazzola, M., P.A. Halvan, and L. Orci. 1996. Inositol 1,4,5-trisphosphate receptor subtype 3 in pancreatic islet cell secretory granules revisited. Proc. Natl. Acad. Sci. USA. 93:2745-2748.

29. Koguma, T., S. Takasawa, A. Tohgo, T. Karasawa, Y. Furuya, H. Yonekura, and H. Okamoto. 1994. Cloning and characterization of cDNA encoding rat ADP-ribosyl cyclase/cyclic ADP-ribose hydrolase (homologue to human CD38) from islets of Langerhans. Biochim. Biophys. Acta. 1223:160162.

30. Nata, K., T. Takamura, T. Karasawa, T. Kumagai, W. Hashioka, A Tohgo, H. Yonekura, S. Takasawa, S. Nakamura, and H. Okamoto. 1997. Human gene encoding CD38 (ADP-ribosyl cyclase/cyclic ADP-ribose hydrolase): organization, nucleotide sequence and alternative splicing. Gene. 186: 285-292.

31. Bradford, M.M. 1976. A rapid and sensitive method for the quantitation of microgram quantities of protein utilizing the principle of protein-dye binding. Anal. Biochem. 72:248-254.

32. Takahashi, K., I. Kukimoto, K.I. Tokita, K. Inageda, S.I. Inoue, K. Kontani, S.I. Hoshino, H. Nishina, Y. Kanaho, and T. Katada. 1995. Accumulation of cyclic ADP-ribose measured by a specific radioimmunoassay in differentiated human leukemic HL-60 cells with all-trans-retinoic acid. FEBS Lett. 371: 
204-208

33. Itoh, T., A. Taminato, Y. Kato, H. Natsume, Y. Suzuki, G. Sarwar, and T. Yoshimi. 1997. Modulation of insulin secretion by CD38 antibodies. J. Jpn. Diabetes Soc. 40:211.

34. Yagui, K., F. Shimada, M. Miura, N. Hashimoto, Y. Suzuki, Y. Tokuyama, K. Nata, A. Tohgo, F. Ikehata, S. Takasawa, et al. 1998. A missense mutation in the CD38 gene, a novel factor for insulin secretion: association with Type II diabetes mellitus in Japanese subjects and evidence of abnormal function when expressed in vitro. Diabeteologia. In press.

35. Rojas, E., P.B. Carroll, C. Ricordi, A.C. Boschero, S.S. Stojilkonic, and
I. Atwater. 1994. Control of cytosolic free calcium in cultured human pancreatic $\beta$-cells occurs by external calcium-dependent and independent mechanism. Endocrinology. 134:1771-1781.

36. Ashcroft, F.M., and S.J.H. Ashcroft. 1992. Mechanism of insulin secretion. In Insulin: Molecular Biology to Pathology. F.M. Ashcroft and S.J.H Ashcroft, editors. IRL Press, Oxford, UK. 97-150.

37. Taminato, A., T. Itoh, H. Natsume, Y. Kato, Y. Suzuki, T. Yoshimi, and S. Makino. 1997. Anti-CD38 antibody as a novel autoantibody in IDDM: studies in NOD mice. J. Jpn. Diabetes Soc. 40:203. 